\title{
AGRICULTURAL POLICY REVIEW PART 2: WHEAT BOARD QUOTA SYSTEM
}

FRED THORNTON, JOCE BOWMAN, and DAVID STRUTHERS, Western Resource Management Associates Limited, Box 4-B Site 2, Yorkton, Saskatchewan. S3N 2V4

The roots of the Canadian Wheat Board go back to the early 1900 s when farmers operated their own wheat cooperatives. During the First World War, the federal government established a national sales agency, the Board of Grain Supervisors, to market wheat. When the war ended a Canadian Wheat Board was temporarily established to help the grain market revert to peace time conditions. This board operated for only one year and, during that time, introduced the concept of centralized selling to farmers.

Prairie farmers recognized two major advantages from such a marketing agency:

1) The initial guaranteed minimum payment received when their wheat was delivered to country elevators; and

2) The concept of price pooling, where all profits from the sale of wheat were returned to the farmer and each farmer received the same price for the grain and grade delivered.

Price pooling was particularly attractive because it smoothed out the annual highs and lows of fluctuating grain prices. Farmers who were un- able to deliver grain when prices were at their highest did not have to suffer large losses.

Farmers began to lobby the federal government for the establishment of a permanent wheat board. This pressure, and the economic conditions arising from the depression, led to the creation of the present Canadian Wheat Board (CWB) by an act of Parliament in 1935. The CWB originally marketed only wheat and use was voluntary. In 1943 it became compulsory for farmers to market their wheat through the CWB. During 1949, CWB powers were extended to include oats and barley, however, oats reverted to a non-Board grain in 1989. The CWB is the world's largest grain marketing board and merchandiser of wheat and barley. It is one of Canada's largest corporate enterprises and our single, largest exporter.

The CWB's Role The CWB is western Canada's only marketing agency for wheat and barley sold on export or domestic markets for human consumption. Wheat and barley suitable only for domestic livestock feed can be sold through the CWB or through independent companies. Other cereal grains and oilseeds grown in western Canada (i.e., oats, rye, flax- 
seed, canola) are considered nonBoard grains and marketed through independent grain companies. However, the CWB sets delivery quotas for these grains. These quotas regulate the flow through the elevator system at rates which meet shortterm market requirements and provide producers with an equal opportunity to deliver both Board and non-Board grains.

The CWB provides farmers with an initial payment when they deliver grain to an elevator. The initial payment is generally set below prevailing world grain prices. The federal government is responsible for setting the level of the initial payment and guaranteeing this payment to farmers. This initial payment can be increased during the crop year, but it cannot be reduced. If an increase occurs, adjustments are sent to farmers who have already delivered grain.

The CWB sells the grain and pools the total returns from those sales. The pool accounts are wheat, durum wheat, barley, and designated barley (high quality barley for malting or pearling). The CWB then distributes the final payment to the producer based on the amount and grade of grain delivered. Each farmer receives the same rate of payment for the same type and grade of grain, no matter when it is delivered in the crop year. In some years, revenue from grain sales is less than the initial payment plus marketing costs. When this happens, farmers do not receive a final payment for their grain and the federal government must cover the cost to the pool account.

CWB Structure The employees of the CWB are not civil servants. All salaries and operating expenses of the Board are paid by farmers rather than the federal treasury. Board commissioners and senior executives meet regularly with a Producer Advisory Committee, which is elected by farmers. The CWB holds annual meetings throughout the prairies where farmers' concerns can be presented.

The CWB has ties to the federal government. The government is responsible for setting the initial price to farmers and also appoints commissioners to the Board. The Board reports to a designated minister and produces an annual report on its operations. The federal government guarantees payment on credit sales made by the Board.

The CWB Quota System The CWB cannot take delivery of all the grain at harvest, therefore, it establishes quotas on grain deliveries to bring forward the amount of grain necessary to meet market demands. Every farmer has a quota base that is used to calculate the quantities of grain that can be delivered when quotas are announced. The quota base is calculated using the following parameters: ${ }^{2}$

1) Acres of farmland seeded to the six quota grains (wheat, oats, barley, rye, flax, and rapeseed);

\section{2) Acres of farmland in summer- fallow;}

3) Acres of farmland planted to miscellaneous crops (all crops other than quota crops and perennial forage); and

4) Acres of farmland seeded to perennial forage. Forage acreage in the quota base cannot be more than one-third of the total acreage in quota grains, summerfallow, and miscellaneous crops. If the acreage 
of perennial forage exceeds the allowable one-third limit, the surplus forage acreage cannot be used in the quota base calculation.

To determine the total acreage eligible for quota allotment, the acres of land in any of the six quota grains, summerfallow, and miscellaneous crops are added together plus onethird of that total or the number of acres in perennial forage (whichever is the smaller number). If the summerfallow plus miscellaneous crop acreage is less than one-third of the total area seeded to the six quota grains, producers are entitled to bonus quota acres. Bonus quota acres are determined by calculating onethird of the area seeded to the six quota grains minus the acreage of summerfallow and miscellaneous crops. The resulting figure constitutes the producer's bonus quota acres and are added to his total quota allotment. Bonus quota acres allow producers who continuous crop to deliver a greater percentage of their total production. Land which has been newly broken becomes eligible for inclusion in the calculation of assignable quota acreage in the subsequent crop year.

The manner in which the quota allotment acres are distributed amongst the quota grains produced by the farmer is totally at his/her discretion. ${ }^{8}$ For crops such as wheat, as a rule, farmers assign at least twice as many quota acres than are actually seeded. This method of assigning quota acres provides farmers whose yields are well in excess of annual quota allotment a greater opportunity to sell grain stocks.

Potential Impacts to the Landscape Despite the benefits of its marketing services, some of the CWB procedures, particularly the grain quota system, were designed with little consideration for long-term environmental consequences. A number of studies, over the past ten years, have identified the negative impacts of the quota system on the resource base and the environment. ${ }^{1,3,4,5,6,8}$ Some of these impacts are:

\section{1) The quota system encour- ages excessive summerfallow.} The inclusion of summerfallow acreage in the quota acreage calculation may encourage a greater extent and frequency of summerfallowing, a practice which leads to increased soil salinization, erosion, and lower soil productivity. Quota deliveries are based on the number of acres cultivated by the producer as opposed to the number actually seeded to quota crops. Esquirol suggests that because it is more economical to produce to the limit on some fields and save input costs on others, many farmers have seen fit to cultivate all their land and then let some remain fallow. ${ }^{3}$ Farmers receive the benefit of having the acres included in the calculation of their quota, without the cost of inputs that a seeded acre would have.

Bond summarizes the CWB's response to this impact. ${ }^{1}$ The CWB notes that: (1) quota policy is less likely to increase summerfallow due to the low volume of stored grain in recent years; and (2) that summerfallow practices for soil moisture retention remain essential for farming in arid regions of the prairies. The CWB suggests that the most expedient approach to reducing soil degradation would involve increased extension efforts to promote good soil husbandry and soil conservation measures on land in fallow, such as reduced tillage and stubble management. 
2) The quota system encourages the cultivation of marginal land. Currently, producers are granted rights to market a certain number of bushels for each unit of land which is considered cultivatable. Therefore, there is an economic advantage to break land in order to obtain additional quota acres. The stipulation that land must be broken before it can be assigned quota acres encourages farmers to consider native lands as a potential reserve for expanding their quota base. ${ }^{8}$ The continuing expansion of cultivation into native lands only aggravates the environmental degradation of the prairie landscape. Given the high degree of agricultural alteration that has already taken place on the prairies the remaining wetlands, shrublands, and other sensitive areas would, from a social, aesthetic, and ecological perspective, best be retained in their native state. Zittlau claims that, with the push to continuous cropping as a more sustainable form of agriculture, the cultivation of marginal land could become an increasingly attractive option for some farmers wishing to expand their quota base. Continuous cropping results in increased production and a reduction in summerfallow acres. If the additional seeded acreage is used to produce Board grains, the increased volume could result in large surpluses, smaller quota releases, and reduced delivery opportunities for individual farmers. In reaction to this concern the CWB introduced the bonus quota acre calculation in an attempt to promote extended crop rotations. However, the increase in quota acreage achieved through this program is not a disincentive to bringing additional land into cultivation.

3) The quota system does not allocate marketing rights according to the productivity of the land. The current quota policy permits a farmer to sell a specific number of bushels per unit area, regardless of his actual yields. Such a system does not make allowances for the differences in productivity between farms and agricultural landscapes. A farmer who produces consistently smaller yields, in a climatically marginal area and/or on lower capability soils, will be able to deliver a larger percent of his production than a farmer in a higher yielding area. Bond suggests that this tends to cause a shift of grain production away from areas of higher rainfall and fertility to areas of lower soil capability that are more vulnerable to drought. ' In areas of higher production, farmers compensate for their inability to deliver the same percentage of their total wheat production by shifting cropping patterns away from grains to specialty crops.

4) Constant quotas deter the implementation of highly efficient production techniques and may discourage increases in productivity on potentially productive land. Under an acreage-based system there is no incentive to increase yields since the percent of deliverable production does not increase. Increased production results in more on-farm grain storage. Practices helping to rebuild soils are not rewarded, but are actually discouraged, since the extra production resulting from good soil management is not included in the quota calculation. As well, constant quotas may have regional impacts on soil degradation. Areas of higher rainfall are generally most suitable for continuous cropping and the elimination of summerfallowing. These areas have higher yields, but constant quotas reduce the proportion of the crop that can be sold there, in comparison to more marginal areas, thereby providing the least incentive to reduce summerfallow in areas with the best 
potential to do so.

According to Bond the CWB feels that: ${ }^{1}$ (1) Land in summerfallow has been steadily declining, particularly in areas of the prairies receiving adequate rainfall; (2) wheat yields have tended to increase reflecting, at least in part, more intensive farm management; (3) many farmers choose, on their own accord, to diversify their operation into other crops and livestock in order to reduce their economic vulnerability to grain markets; and (4) along with the quota system, the CWB also offers contracts for certain grains (e.g., soft white spring wheat), some of which can only be grown in certain areas. As a result, these contracts allocate marketing rights according to the productivity differences between farm areas.

5) CWB policies are disincentives towards diversification, particularly to livestock and forage production. In fact, they pressure farmers towards specialization in grain, particularly wheat and barley. This occurs because of the emphasis that the quota system places on the production of Board grains for export. In addition, the bonus quota acres program negatively affects crop diversification. The bonus acres calculation actually penalizes producers having more than one-third of their annually seeded acreage devoted to specialty crops. Such practices tend to increase the area in Board grains and reduce the production of specialty crops.

The CWB has observed that the area seeded to specialty crops on the prairies is increasing, thereby indicating that the bonus acres program has not reversed the trend. ${ }^{1}$

6) The quota system does not en- courage extensive use of forages in areas of intensive livestock production and areas prone to soil erosion. Total forage acres can only comprise one-third of the total crop acreage for the calculations of the quota base.

Most of the above problems have been examined in the ongoing process of agricultural policy review, but none have been resolved.

Possible Solutions Esquirol recommends that the quota system be examined with a view towards making the system a conservation facilitator. ${ }^{3}$ To accomplish this, he recommends that grain deliveries from farms be based on a volume, rather than an acreage, basis. Girt supports this approach. ${ }^{4}$ Also, the Saskatchewan Wetland Conservation Corporation (SWCC) includes it, as an option for modifying the quota system, in their policy review: An Inventory of Agricultural Policy Impacts on Wildlife and Options for Reform. ${ }^{7}$

In such a system, farmers would set delivery contracts with the CWB in which they would commit the amount of grain they wish to sell during a particular delivery period. The CWB would then call forward a percentage of the grain offered during that time period. Esquirol states that such a system would ensure the primary objectives of the quota system (i.e., enhancing marketability and providing equity in delivery opportunities). ${ }^{3}$ Productivity would be rewarded because each producer would contract his actual inventory, regardless of the area of land used in the production of grain. The cultivation of fragile or unproductive land would become much less viable, economically.

Esquirol sees other important 
benefits arising from a volume-based quota system. ${ }^{3}$ These include the encouragement of sound soil management techniques such as manure application, shelterbelts, specialty crops in rotation, and the prudent use of forages. These techniques would provide increased delivery opportunities through an increased production volume. A volume-based quota system may result in the regrassing of eroded soils, reclamation of saline areas through the seeding of salt-tolerant perennials, and reassessment of the destruction of wildlife habitat on marginal land since these areas do little to add to the volume of production.

There is no reason why a more intensive, rather than extensive, production program should result in decreases in production. If the monies used to produce grain on marginal land were applied to optimize production through sustainable soil and landscape management on more fertile acres, total production would likely remain the same, or perhaps even increase.

Zittlau proposed three modifications to the quota system: ${ }^{8}$

1) Remove from the quota acreage formula any provisions which encourage farmers to invade marginal lands;

2) Modify the practice of including cultivated summerfallow in the quota acreage formula; and

3) Alter the quota acreage formula to permit the inclusion of native pasture and/or uncultivated lands in quantities equal to a predetermined percentage of cultivated acreage.

Zittlau also recognizes that, prior to implementing any changes to the quota system, the full economic implications of those changes must be considered. ${ }^{8}$ If this were not done, there could be economic upheavals that could create even more serious environmental problems. To minimize economic complications that may arise Zittlau recommends that changes be implemented over a 5 to 10 year transition period. ${ }^{8}$

The SWCC outlines an additional option for modifying the CWB quota system on very small acreages. ${ }^{7}$ This option would modify the existing quota system to include "marketable habitat quota acres." These habitat quota acres would be leased, on an annual basis, by some other agency or interest group (e.g., Ducks Unlimited, SWCC, etc.). This option is specifically aimed at securing uplands associated with good wetland habitat. Following an application, assessment, and approval procedure, eligible farmers could receive 3 to 10 acres of Habitat Quota for each acre converted to perpetual habitat. The amount of land placed in such a plan would be negotiated as would the ratio of quota acres to habitat acres.

In summary, the CWB quota system was enacted to standardize delivery of grain to supply markets that the CWB had developed. However, this system, in ensuring grain supplies for short-term market growth, is detrimental to the long-term view of sustainable land productivity. In association with other agricultural policies, the quota system has moulded a production system on the prairies that realizes short-term subsidy benefits from the cultivation of marginally productive land, continues to allow soil erosion through summerfallow, and encourages the production of annual crops in areas with inadequate climate. The agricultural industry of today needs to focus its 
energy on the major issues of sustainability and diversification and discard the antiquated CWB quota system that discourages both sustainable soil and land management and diversification from grain production.

1. BOND, W.K., H.C. BRUNEAU and P.D. BIRCHAM. 1986. Federal programs with the potential to significantly affect Canada's land resource. Lands Directorate, Environment Canada. Ottawa. 249 pp.

2. CANADIAN WHEAT BOARD. 1982. Bonus acres and... those 1982-83 permit applications/the nuts and bolts of quotas. pp. 2-3. In: Grain Matters, June/July 1982. Canadian Wheat Board, Winnipeg, Manitoba.

3. ESQUIROL, H. 1988. The effect of the Canadian Wheat Board quota policy on soil and water conservation. Western Canadian Wheat Growers. Presented at the Sixth Annual Western Provinces Conference on the Rationalization of Soil and Water Management. Winnipeg, Man. Nov. 28-30, 1988. $16 \mathrm{pp}$.
4. GIRT, J. 1990. Common ground: recommendations for policy reform to integrate wildlife habitat, environmental, and agricultural objectives on the farm. Wildlife Habitat Canada. 56 pp.

5. LEBLOND, G. 1990. Growing together. Report to the Federal-Provincial Agricultural Committee on Environmental Sustainability. $41 \mathrm{pp}$.

6. RAKOWSKI, P.W., and J.R. JURICK. 1980 (Revised 1986). A review of legislation to determine its effects on migratory bird habitat. Manuscript Report No. WNR 86-3. Canadian Wildlife Service. $108 \mathrm{pp}$.

7. REIMER, G. 1992. An inventory on wildlife and options for reform. Saskatchewan Wetland Conservation Corporation. Unpublished report. 11 pp.

8. ZITTLAU, W.T. 1979. An environmental assessment of agricultural practices and policies: implications for waterfowl habitat management. The Natural Resource Institute, University of Manitoba. Winnipeg. 282 pp.

[This article is published under the auspices of the Saskatchewan Natural History Society - Endangered Species and Spaces Committee and is the second in a four-part series on the effects of agricultural policy in Saskatchewan.]

Never mind Northern Spotted Owls, hunters in the United States could be an extinct species within 35 years, according to a sociology professor at the University of Wisconsin-Madison. Tom Heberlein, who is also a deer hunter, predicts:

- The aging of society in general and hunters in particular will decimate the present legions of hunters.

- Youngsters, distracted by other recreational pursuits, will simply not replenish the hunting ranks.

- Declining populations in rural areas - the cradle of hunting - will reduce further the pool of potential hunters.

- Animal-rights activists have, to some extent, turned public opinion against hunters.

- The Globe and Mail, 8 December 1992. 